\title{
FRONT-LINE EMPLOYEE DEVIANCE, ENCOUNTER SATISFACTION AND CUSTOMER CITIZENSHIP BEHAVIOR: AN EXPERIMENTAL DESIGN
}

\author{
Achillleas Boukis, University of Sussex, UK, a.boukis@ sussex.ac.uk \\ Nikoletta-Theofania Siamagka, King's College, UK, nikoletta.siamagka@kcl.ac.uk \\ Farhana Tabassum, University of Sussex, UK, farhanatabassum.r@ hotmail.com \\ Minas Kastanakis, ESCP Europe, UK, mkastanakis@ escpeurope.eu
}

\begin{abstract}
While to date, the phenomena of employee deviance and customer citizenship behavior have overwhelmingly been studied in an isolated and disparate fashion. This empirical effort lays the ground for exploring the impact of employees' deviant behavior under different conditions on repurchase intention, customer citizenship behavior (CCB) towards the company and encounter satisfaction during a specific service incident. Understanding the impact of employee deviance on customers' experience during the service encounter remains crucial as the costs of deviant behavior to the organization primarily impair service quality and possibly discourage customers from repeat business (Harris and Ogbonna, 2012). Most relevant studies mainly focus on negative aspects of employee deviance, ignoring the existence of customer-oriented deviant behaviors which can positively affect customer experience during the service specific transaction (Stock and Bednarek, 2014). Despite the focus on some organizational and individual determinants of deviant employee behavior such as job control or need for social approval (Brady et al., 2012), the extant research rarely acknowledges how various types of deviant employee activity affect customer perception of the FE or the organization (Daunt and Harris, 2013). Equally important, the role of employee deviance during the service encounter for customer citizenship (or dysfunctional) behavior has never been considered, despite calls to identify the organizational-based determinants of customer deviant behavior (Boo et al., 2013; Gong et al., 2013).

This study adopts an experimental design with the aim of examining the impact of employee deviance on encounter satisfaction, repurchase intention and customer citizenship behavior (CCB) towards the company. In particular, a $3 \times 2 \times 2$ between-subjects experiment was conducted which examines the effects of employee deviance on customer outcomes under different conditions. The independent variables manipulated were employee deviance towards customer (positive, negative or no deviance), whether the problem the customer faces is severe or not (high and low severity) and whether the outcome of the interaction was successful or not (successful or unsuccessful final outcome). Taken together, the results of this study suggest that different types of employee deviance affect customer outcomes in different ways. For the very first time, the effect of employee deviance on customer citizenship behavior is empirically confirmed. When employees display a negative deviant behavior towards customers, the chances for reciprocating the company with customer citizenship behavior are significantly lower than when employees display a positive deviant behavior towards customers.
\end{abstract}

